\title{
The genetic structure of longevity in dairy cows
}

\author{
Johannes Heise ${ }^{*} \dagger^{1}$ Zengting Liu, $\nmid$ Kathrin F. Stock, $\uparrow$ Stefan Rensing, $\dagger$ Friedrich Reinhardt, $\dagger$ \\ and Henner Simianer* \\ *Animal Breeding and Genetics Group, Department of Animal Sciences, Georg-August-Universität, 37075 Göttingen, Germany \\ †Vereinigte Informationssysteme Tierhaltung w.V. (VIT), Heinrich-Schröder-Weg 1, 27283 Verden, Germany
}

\begin{abstract}
Longevity of dairy cows is determined by culling. Previous studies have shown that culling of dairy cows is not an unambiguous trait but rather the result of several reasons including diseases and selection decisions. The relative importance of these reasons is not stable over time, implying that genetic background of culling may vary over lifetime. Data of 7.6 million German Holstein cows were used to assess the detailed genetic correlation structure among 18 survival traits defined for the first 3 parities. Differences of genetic factors which determine survival of different production periods were found, showing a pattern with 3 genetically distinct periods within each parity: early lactation (calving until d 59), mid lactation (d 60 to 299), and late lactation (d 300 until next calving). Survival in first and later parities were found to be slightly genetically different from each other. The identified patterns were in good accordance with distributions of reasons for disposal, and correlations of estimated breeding values of survival traits for different periods to production and functional traits were generally plausible compared with literature regarding effects on the risk of culling. The study shows that genetic background of survival is variable not only across but also within parities. The results of the study can help developing more accurate models for routine genetic evaluations of longevity that account for nonunity genetic correlations between survival of different periods.
\end{abstract}

Key words: longevity, culling, dairy, genetics

\section{INTRODUCTION}

Longevity of dairy cows is an economically important trait for farmers (Allaire and Gibson, 1992) and has gained in importance as a global indicator for animal

Received July 23, 2015.

Accepted September 16, 2015.

${ }^{1}$ Corresponding author: johannes.heise@vit.de welfare (Thomsen and Houe, 2006; Pritchard et al., 2013). In the last decades, numerous studies have shown that longevity is heritable, and routine genetic evaluations for longevity are conducted in all major countries of dairy breeding (Miglior et al., 2005; Interbull, 2015). Longevity results from survival at successive time periods. It is genetically often treated as the same trait over the whole life of a cow (Ducrocq, 1994; Caraviello et al., 2004; González-Recio and Alenda, 2007; Pritchard et al., 2013). However, several studies suggest that survival of different parities is genetically different (Visscher and Goddard, 1995; Boettcher et al., 1999; Veerkamp et al., 2001; Sewalem et al., 2007; Holtsmark et al., 2009). Previous studies further showed that effects of different diseases (Beaudeau et al., 1994; Gröhn et al., 1998; Rajala-Schultz and Gröhn, 1999a) and reproduction traits (Rajala-Schultz and Gröhn, 1999b; Bicalho et al., 2007) on culling are dependent on the parity and also on the stage of lactation. This implies that genetic background of survival of different periods within the same lactation may differ (Ducrocq, 1999). This hypothesis is supported by distributions of disposal reasons reported by dairy farmers, where distribution patterns depend on the parity and the stage of lactation (Seegers et al., 1998; Pinedo et al., 2010). Roxström and Strandberg (2002) found culling for different reasons to be genetically different and $\mathrm{Du}$ crocq (2002) found strong indications that survival late in lactation is genetically distinct to survival early in lactation regardless of lactation number. van Pelt et al. (2015) reported the genetic background of survival to be changing over time, using definitions of survival traits based on the overall length of productive life. Lactation-based definitions of monthly survival were only recently examined by Sasaki et al. (2015) in Japanese dairy cattle using a random regression model.

The aim of our study was a systematic investigation of the genetic structure of longevity regarding different periods of first, second, and third parity. Distributions of disposal reasons and correlations of estimated breeding values for the new survival traits to various production and functional traits were used to validate the genetic correlation patterns found. Because survival 
and threshold models are computationally highly demanding and thus not feasible for extensive multivariate genetic analyses on large data sets (Boettcher et al., 1999), a linear multiple trait model was chosen for the refined survival analyses.

\section{MATERIALS AND METHODS}

\section{Data}

For this study, records of Holstein dairy cows used in the German routine genetic evaluation for longevity were available. Data were restricted to years of first calving between 1998 and 2014, with cutoff date February 10, 2014. Records included dates of birth and calving, the herd code, and in case the cow had left the herd, the reason for and date of disposal. Only records with complete and valid data between first and last observed calving were considered. This means, for example, for a cow that was culled or censored during the third lactation, records of the first and second lactation had to be present in the data set. Records of cows with unknown sires or age of first calving outside the range of 500 to $1,500 \mathrm{~d}$ were excluded. Herds had to have at least 15 calvings for each year in the observation period between 1998 and 2013 (data for year 2014 were not complete). After editing, 7,684,455 records remained on the data pool for the analysis of survival.

For parameter estimation, data were further restricted to years of first calving from 1998 to 2008, such that each cow in the data had the opportunity to finish at least 3 lactations. Because estimation of variance components would not have been computationally feasible on the full data set, 10 possibly overlapping samples of 200 herds each were randomly drawn. To avoid sparse category problems, only data of 5 out of the 16 federal states were considered. Each sample consisted of an average of 234,498 records of daughters from 7,103 bulls. Over all samples, a total of 1,495,441 different cow records were used for parameter estimation. Data structure by lactation is shown in Table 1 .

\section{Distribution of Disposal Reasons}

In Germany, disposal reasons are recorded routinely when a cow exits milk recording. The farmer is requested to report his/her main reason for disposal as one of the predefined disposal reasons: infertility, udder diseases, claw and leg disorders, metabolic diseases, other diseases, poor milk yield, milkability, age, other reasons, or sold for dairy purposes. Only cows being disposed for reasons other than "sold for dairy purposes" were considered. Frequency distributions for disposal reasons were computed by parity and relative to calving by $10-\mathrm{d}$ intervals for days in milk.

\section{Trait Definition}

Traits were defined as survival of different periods of the first 3 parities. Genetic analyses were carried out using 2 different period definitions. First, for evaluating the genetic structure of survival in detail, 2-mo periods were defined (A). Second, adjacent periods from A with minimum genetic correlations of 0.9 were joined such that fewer periods (B) were defined to achieve a simpler model for genetic evaluations. Period definitions for A and $\mathrm{B}$ are specified in Table 2. In each case, records were coded as 1 if a cow was still alive at the end of the period and 0 if culling occurred during the period. Records of cows which were culled in a previous period or censored during a period were noninformative with regard to survival and therefore not considered. Censoring was assumed when the date of disposal was missing or when the disposal reason was "sold for dairy purposes." In other words, trait n was defined as survival at the end of period $n$, given the cow was still alive at the end of the period $n-1$.

\section{Model for Genetic Analyses}

The basic model equation for all linear multiple trait models was

$$
\mathbf{y}=\mathbf{X b}+\mathbf{Z s}+\mathbf{e}
$$

where $\mathbf{y}$ is a vector of survival $(0 / 1)$ observations, $\mathbf{X}$ is an incidence matrix linking the observations to the fixed effects, $\mathbf{b}$ is the vector of fixed effects (i.e., the effect of herd $\times$ year of calving for each period), $\mathbf{Z}$ is the incidence matrix of random sire effects, $\mathbf{s}$ is the vector of random sire effects $\left[\mathbf{s} \sim N\left(0, \mathbf{G}_{0} \otimes \mathbf{A}\right)\right]$, with the genetic covariance matrix $\mathbf{G}_{0}$ and the numerator relationship matrix for sires $\mathbf{A}$ ), and $\mathbf{e}$ is a vector of random residual effects $\left[\mathbf{e} \sim N\left(0, \mathbf{R}_{0} \otimes \mathbf{I}\right)\right]$, with the residual covariance matrix $\mathbf{R}_{0}$ ). Models using trait defini-

Table 1. Distribution of records by lactation

\begin{tabular}{lcc}
\hline & \multicolumn{2}{c}{ Number of records } \\
\cline { 2 - 3 } Lactation & $\begin{array}{c}\text { Parameter } \\
\text { estimation }\end{array}$ & $\begin{array}{c}\text { Breeding value } \\
\text { estimation }\end{array}$ \\
\hline 1 & $1,495,441$ & $7,684,455$ \\
2 & $1,137,682$ & $5,370,587$ \\
3 & 790,602 & $3,499,842$ \\
\hline
\end{tabular}


Table 2. Definitions of periods for survival traits

\begin{tabular}{llccc}
\hline & & \multicolumn{3}{c}{ Parity } \\
\cline { 3 - 4 } Trait definition & Days from calving & 1 & 2 & 3 \\
\hline A & $0-59$ & $\mathrm{~A} 1.1$ & $\mathrm{~A} 2.1$ & $\mathrm{~A} 3.1$ \\
& $60-119$ & $\mathrm{~A} 1.2$ & $\mathrm{~A} 2.2$ & $\mathrm{~A} 3.2$ \\
& $120-179$ & $\mathrm{~A} 1.3$ & $\mathrm{~A} 2.3$ & $\mathrm{~A} 3.3$ \\
& $180-239$ & $\mathrm{~A} 1.4$ & $\mathrm{~A} 2.4$ & $\mathrm{~A} 3.4$ \\
& $240-299$ & $\mathrm{~A} 1.5$ & $\mathrm{~A} 2.5$ & $\mathrm{~A} 3.5$ \\
& 300 to next calving & $\mathrm{A} 1.6$ & $\mathrm{~A} 2.6$ & $\mathrm{~A} 3.6$ \\
$\mathrm{~B}$ & $0-59$ & $\mathrm{~B} 1.1$ & $\mathrm{~B} 2.1$ & $\mathrm{~B} 3.1$ \\
& $60-299$ & $\mathrm{~B} 1.2$ & $\mathrm{~B} 2.2$ & $\mathrm{~B} 3.2$ \\
& 300 to next calving & $\mathrm{B} 1.3$ & $\mathrm{~B} 2.3$ & $\mathrm{~B} 3.3$ \\
\hline
\end{tabular}

tions $\mathrm{A}$ and $\mathrm{B}$ are further referred to as model $\mathrm{A}$ and $\mathrm{B}$, respectively.

\section{Estimation of Variance Components}

To make the parameter estimations computationally feasible, the multivariate analyses were split up such that 6 traits each were included simultaneously. Each 6 -trait combination was run on each of the sample data sets described above. This resulted in 150 runs (10 samples $\times 15$ trait combinations) with 6 traits each for model $\mathrm{A}$ and 30 runs (10 samples $\times 3$ trait combinations) with 6 traits each for model B. Variance components were estimated using the VCE software, version 6.0 (Groeneveld et al., 2010). Full covariance matrices were computed as raw means of all genetic parameter estimates from the different runs, ignoring results of runs where convergence was not reached $(12 \%$ of all runs).

\section{Estimation of Breeding Values}

For the genetic evaluation using model B, the genetic variance-covariance matrix $\mathbf{G}$ was composed from the results of the runs of multivariate parameter estimations in 2 steps: first, a matrix $\mathbf{G}_{0}$ was computed, calculating approximate covariances from mean genetic variances and correlations. This matrix was decomposed $\mathbf{G}_{0}=$ $\mathbf{Q} \Lambda \mathbf{Q}^{\prime}$, where $\mathbf{Q}$ is the matrix of eigenvectors of $\mathbf{G}_{0}$ and $\boldsymbol{\Lambda}$ is a diagonal matrix of corresponding eigenvalues. Next, negative eigenvalues in $\boldsymbol{\Lambda}$ were set to 0.001 , resulting in $\boldsymbol{\Lambda}^{*}$ and a positive definite matrix $\mathbf{G}$ was then computed as $\mathbf{G}=\mathbf{Q} \mathbf{\Lambda}^{*} \mathbf{Q}^{\prime}$. The effect of this procedure on the correlation structure was analyzed and found to be negligible (results not shown).

Sire breeding values (EBV) were estimated from the full data set with the PEST software (Groeneveld, 2006). To validate distinct genetic correlation patterns of survival, Pearson correlation coefficients were computed between raw EBV of the particular survival traits and raw EBV of various production and functional traits from the routine national genetic evaluation for dairy cattle. Considered traits from the routine genetic evaluations were functional longevity, milk production (index), SCS, stillbirth (maternal), and first to last insemination as described in the official documentation of the routine genetic evaluation for Holsteins in Germany (VIT, 2015).

Correlations of EBV were computed for sires that were born before 2005 and had more than 50 daughters with a first calving and a minimum reliability for the above-mentioned routine EBV of 0.9. All EBV in the comparison were scaled such that higher values indicated genetic disposition for more favorable trait expressions.

\section{RESULTS}

\section{Survival Patterns}

Estimates for the risk of culling and the proportion of survived cows are shown in Figure 1 for trait definition A following Kaplan and Meier (1958). The highest risk of a cow to be culled given that she had survived the previous periods was found at the beginning and end of a parity (e.g., 0.076 for A2.1 and 0.122 for A2.6), whereas it was almost constant for the other periods (0.035 to 0.036 for A2.2 to A2.5). For corresponding periods in parities 1 to 3 , the risk of culling increased over lactations and was highest for A3.6 (0.144). Proportions of $77.5,54.4$, and $33.4 \%$ of all cows were still alive at the end of the last periods of the first, second, and third parity, respectively.

\section{Distribution of Disposal Reasons}

Distributions of disposal reasons by parities 1 to 5 are shown in Figure 2 for cows that were culled during the years 2010 to 2013. Parities 4 to 5 are shown to assess possible differences to earlier parities. Across 
the considered parities, the main reasons for culling were infertility $(20.4 \%)$, udder diseases $(14.7 \%)$, claw and leg disorders (12.2\%), and other reasons (30.7\%). Differences in the distributions between first and later parities occurred mainly for poor milk yield, milkability, udder diseases, metabolic diseases, and other diseases, whereas distributions for infertility and claw and leg disorders were similar over parities. Frequencies for metabolic diseases, other diseases, and for the first parity, poor milk yield and milkability peaked early in lactation, whereas udder diseases, and claw and leg disorders showed highest incidences in the middle of a lactation (about 60-180 d from calving). The frequency of infertility as a disposal reason increased toward the end of the lactation for all parities and reached $50 \%$ for the interval 490 to $499 \mathrm{~d}$ from calving for the second parity.

\section{Genetic Parameters from Model A (6 Periods Per Parity)}

As shown in Table 3, mean estimates of heritabilities on the observed scale ranged from 0.005 (A1.5) to 0.041 (A3.1) for the 2-mo interval trait definition in model A. First and last periods of a parity showed highest heritability estimates, whereas those for mid-lactation periods were lower and very similar. After transformation, approximate heritabilities on the underlying scale (Dempster and Lerner, 1950) ranged between 0.038 (A1.5) and 0.105 (A3.1). Mean genetic correlations (Figure 3) ranged from $0.37\left(\mathrm{r}_{\mathrm{g}_{\mathrm{A} 1.1, \mathrm{~A} 3.6}}\right)$ to $0.96\left(\mathrm{r}_{\mathrm{g}_{\mathrm{A} 2.1, \mathrm{~A} 3.1}}\right)$.
Standard deviations of genetic correlations over different runs ranged from $0.02\left(\mathrm{r}_{\mathrm{g}_{\mathrm{A} 2.1, \mathrm{~A} 3.1}}\right)$ to $0.2\left(\mathrm{r}_{\mathrm{g}_{\mathrm{A} 1.4, \mathrm{~A} 2.6}}\right)$. First and last periods of a parity showed lower genetic correlations to adjacent periods than the mid-lactation periods. This difference was found to be most extreme in the third lactation where $\mathrm{r}_{\mathrm{g}_{\mathrm{A} 3.1, \mathrm{~A} 3.2}}$ and $\mathrm{r}_{\mathrm{g}_{\mathrm{A} 3.5, \mathrm{~A} 3.6}}$ were 0.73 and 0.61 , respectively, whereas the correlations between adjacent mid-lactation traits ranged from 0.90 to 0.93 . Genetic correlations of periods 1 to 5 of the first parity to corresponding periods of the second parity were lower $(0.80-0.82)$ than genetic correlations between the respective periods of parities 2 and 3 (0.88-0.96). Means for residual correlation estimates were close to zero. All means, standard deviations, and numbers of runs with valid results that were included into the means are provided in Supplemental Table S1 (http://dx.doi.org/10.3168/jds.2015-10163).

\section{Genetic Parameters from Model B (3 Periods Per Parity)}

In model $\mathrm{B}$, periods from model $\mathrm{A}$ with genetic correlations to adjacent periods of $\geq 0.9$ were joined. As shown in Table 4, mean heritability estimates from model B ranged from 0.016 (B1.1) to 0.042 (B3.1). As for model A, heritabilities tended to increase over lactations. In contrast to the third parity, first periods of parities 1 and 2 showed lower or similar heritabilities than later periods of the same lactation. After transformation, approximate heritabilities on the underlying scale (Dempster and Lerner, 1950) ranged between

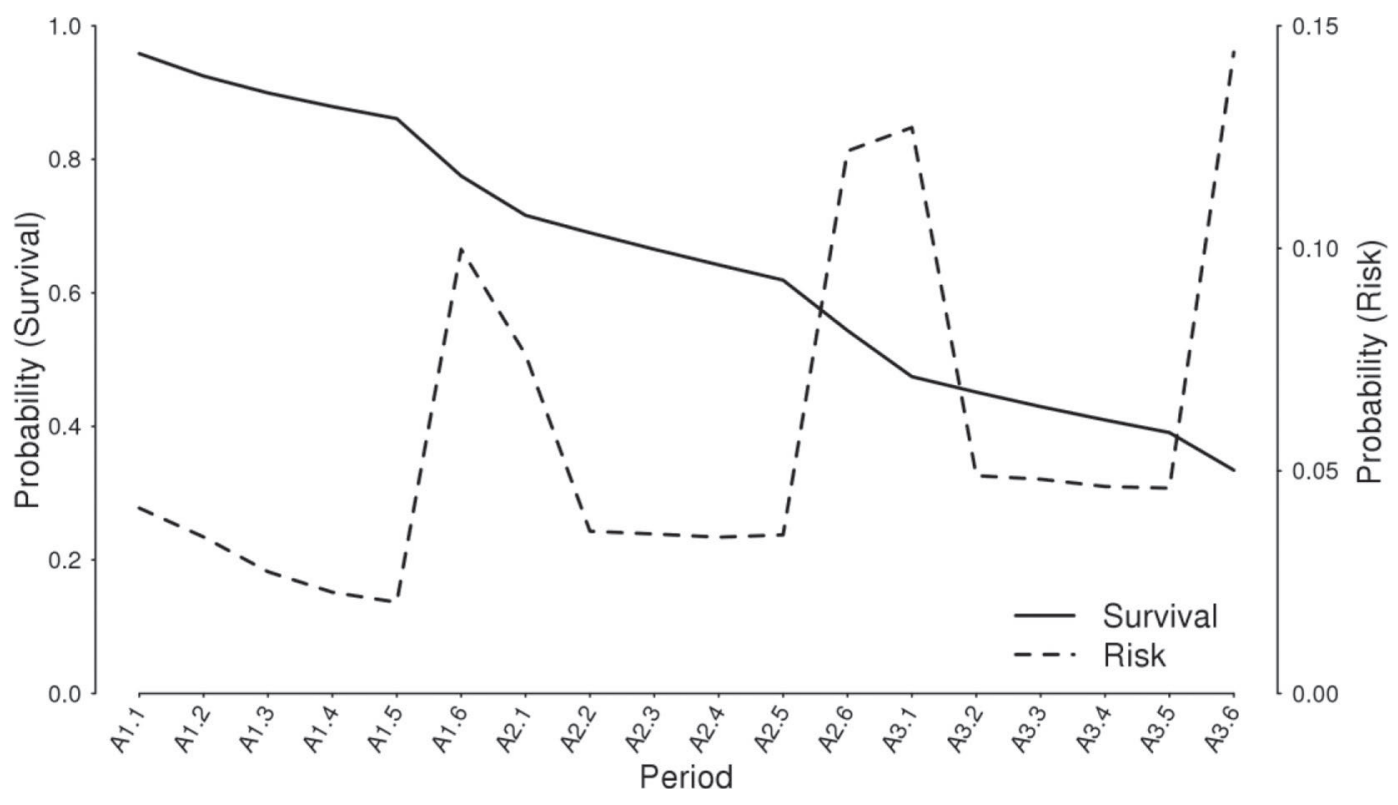

Figure 1. Kaplan-Meier estimators for survival and risk based on trait definition A (6 periods per parity). 
0.053 (B2.3) and 0.107 (A3.1). All mean genetic correlations (Figure 4) between periods of the same parity were below 0.9. Genetic correlations between corresponding periods of successive lactations were higher (0.82 to 0.96 ) than correlations within parity (0.52 to 0.81). Furthermore, corresponding periods of the sec- ond and third parity were higher correlated (0.95 to 0.96 ) than corresponding periods of the first and second parity (0.82 to 0.93 ). The third periods showed high genetic correlations across all parities (0.93 to 0.95). Standard deviations of genetic correlations over the different runs ranged from $0.02\left(\mathrm{r}_{\mathrm{g}_{\mathrm{B} 2.1, \text { в3.1 }}}\right)$ to $0.12\left(\mathrm{r}_{\mathrm{g}_{\mathrm{B} 1.1, \text { Bз.2 }}}\right)$.
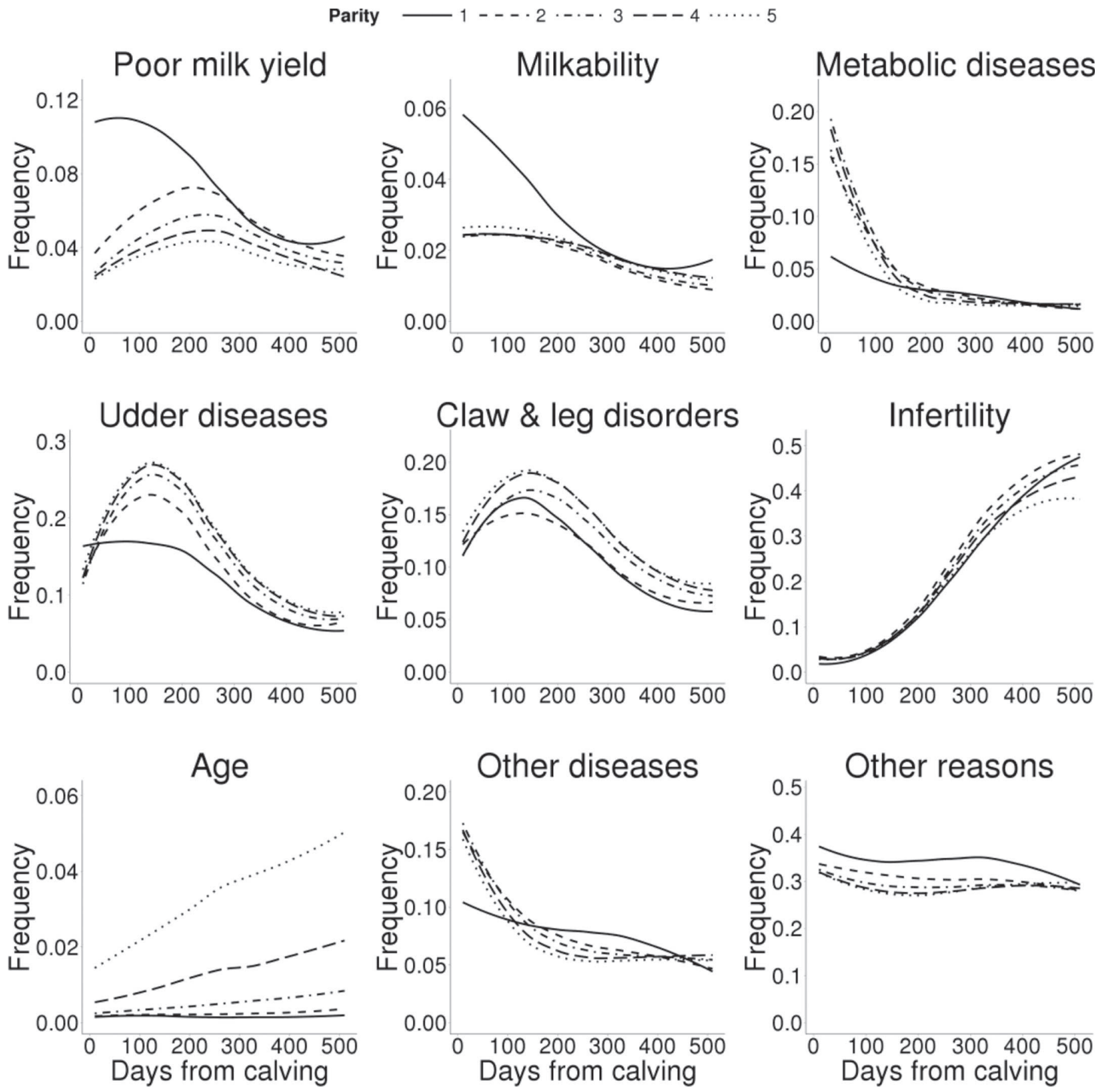

Figure 2. Time-dependent distributions of disposal reasons by parity. Number of disposed cows within each 10-d interval from calving are considered to be $100 \%$. Lines were smoothed with a locally weighted regression based on first-order local polynomials (Cleveland, 1979). 


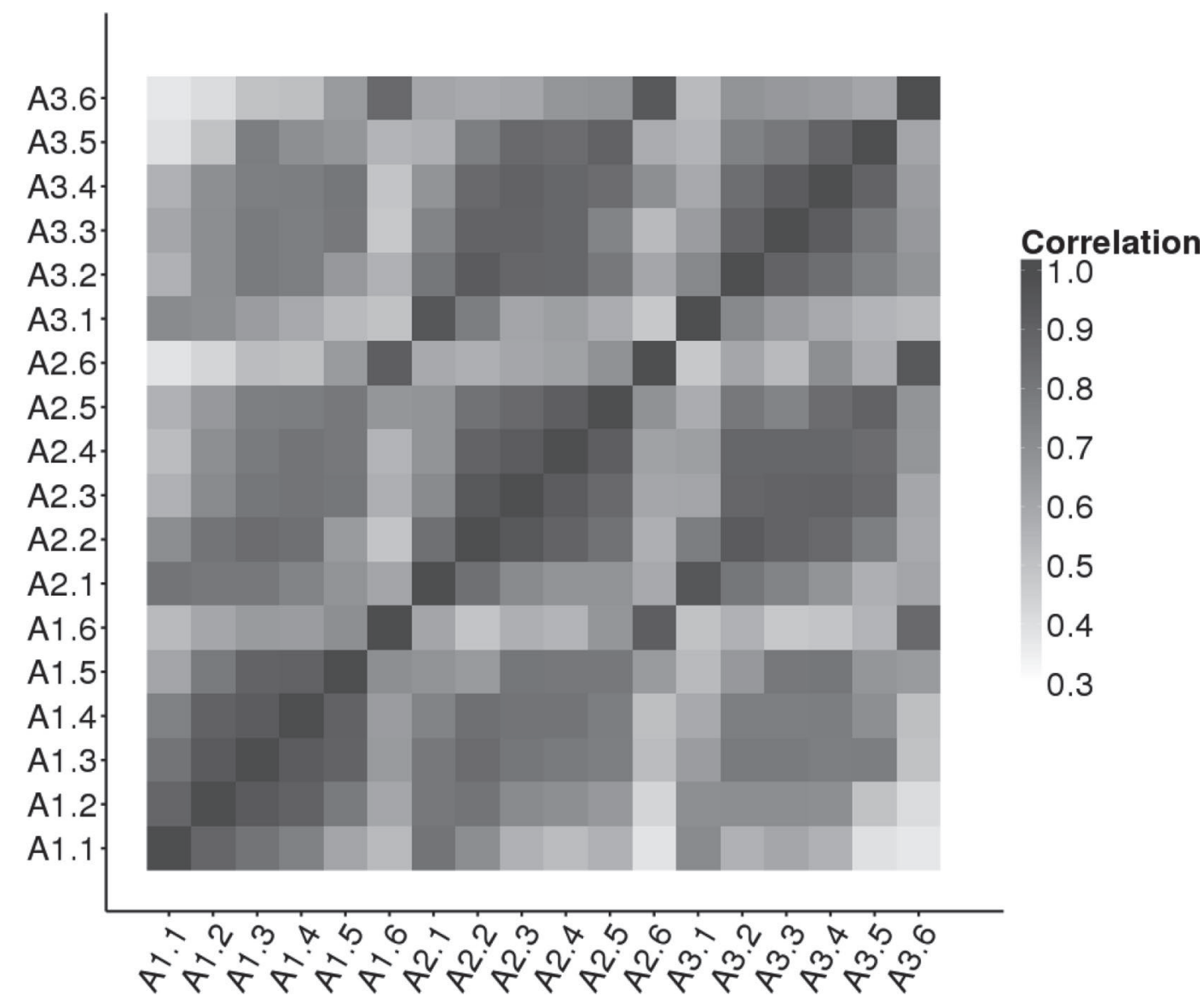

Figure 3. Genetic correlations from model A (6 periods per parity). Estimates are means of genetic correlations from the different runs. The values and standard deviations can be seen in detail in Supplemental Table S1 (http://dx.doi.org/10.3168/jds.2015-10163).

Table 3. Phenotypic frequencies, estimates of heritability from model A (6 periods per parity) on the observed scale and approximated heritabilities on the underlying scale (DL: Dempster and Lerner, 1950) ${ }^{1}$

\begin{tabular}{|c|c|c|c|c|c|}
\hline \multirow[b]{2}{*}{ Trait } & \multirow{2}{*}{$\begin{array}{l}\text { Phenotypic } \\
\text { frequency }\end{array}$} & \multicolumn{2}{|c|}{$h^{2}$} & \multicolumn{2}{|c|}{$\mathrm{h}^{2}(\mathrm{DL})$} \\
\hline & & Mean & $\mathrm{SD}$ & Mean & $\mathrm{SD}$ \\
\hline A1.1 & 0.96 & 0.017 & 0.002 & 0.083 & 0.009 \\
\hline A 1.2 & 0.96 & 0.010 & 0.002 & 0.059 & 0.009 \\
\hline A 1.3 & 0.97 & 0.007 & 0.002 & 0.044 & 0.010 \\
\hline $\mathrm{A} 1.4$ & 0.98 & 0.006 & 0.002 & 0.046 & 0.014 \\
\hline A1.5 & 0.98 & 0.005 & 0.001 & 0.038 & 0.011 \\
\hline A1. 6 & 0.90 & 0.021 & 0.002 & 0.060 & 0.005 \\
\hline A 2.1 & 0.92 & 0.023 & 0.003 & 0.080 & 0.010 \\
\hline A 2.2 & 0.96 & 0.009 & 0.002 & 0.051 & 0.012 \\
\hline A 2.3 & 0.96 & 0.011 & 0.003 & 0.062 & 0.014 \\
\hline A 2.4 & 0.96 & 0.013 & 0.003 & 0.074 & 0.018 \\
\hline $\mathrm{A} 2.5$ & 0.96 & 0.011 & 0.002 & 0.060 & 0.013 \\
\hline A2. 6 & 0.88 & 0.022 & 0.004 & 0.057 & 0.010 \\
\hline A 3.1 & 0.87 & 0.041 & 0.007 & 0.105 & 0.018 \\
\hline A 3.2 & 0.95 & 0.014 & 0.003 & 0.062 & 0.015 \\
\hline A 3.3 & 0.95 & 0.012 & 0.002 & 0.056 & 0.009 \\
\hline A 3.4 & 0.95 & 0.013 & 0.003 & 0.060 & 0.014 \\
\hline A 3.5 & 0.95 & 0.012 & 0.003 & 0.056 & 0.014 \\
\hline A3.6 & 0.85 & 0.027 & 0.004 & 0.064 & 0.009 \\
\hline
\end{tabular}

${ }^{1}$ Heritability estimates are shown with means and standard deviations of estimates from the different runs. 


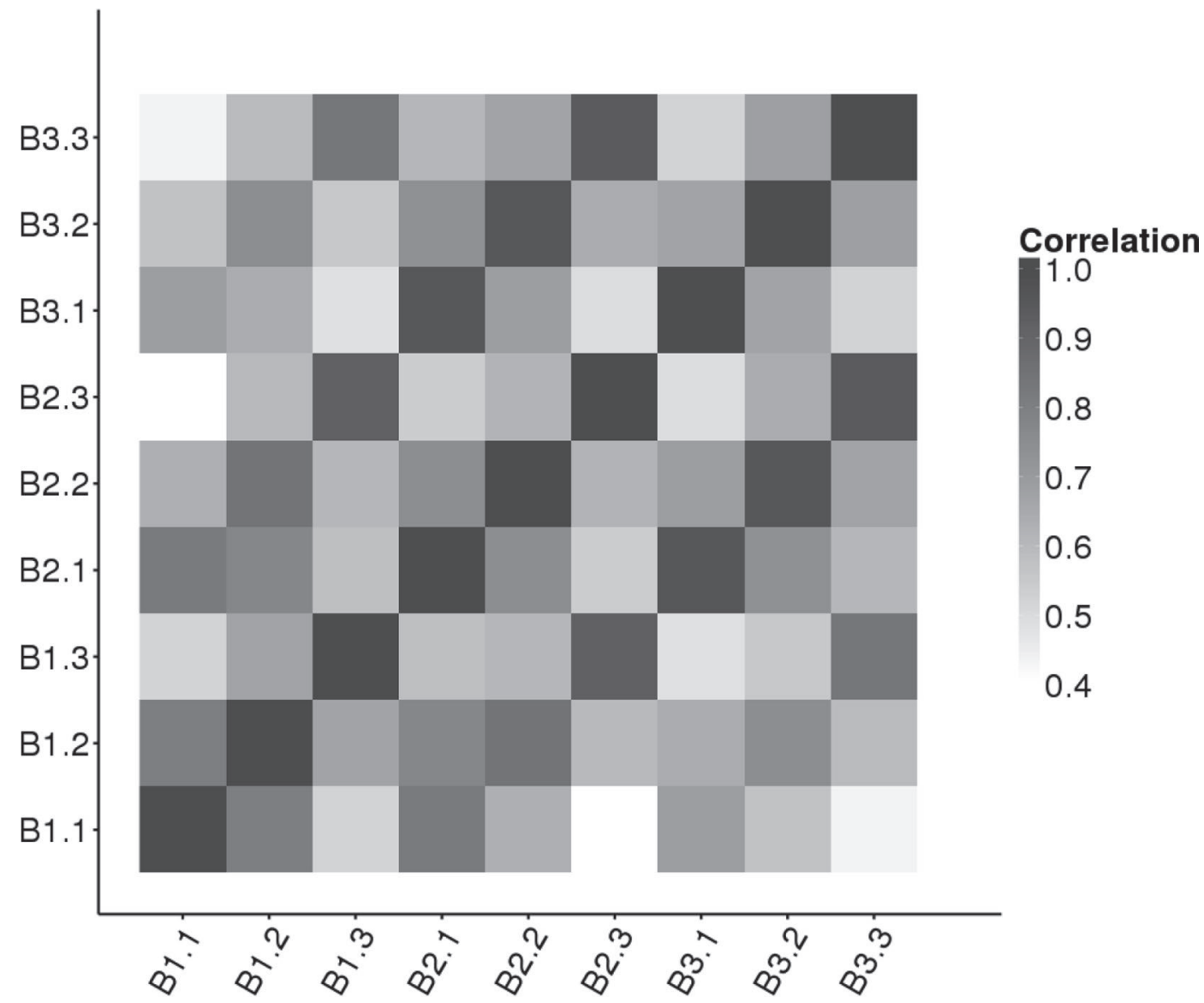

Figure 4. Genetic correlations from model B (3 periods per parity). Estimates are means of genetic correlations from the different runs. The values and standard deviations can be seen in detail in Supplemental Table S2 (http://dx.doi.org/10.3168/jds.2015-10163).

Means for residual correlation estimates were close to zero. All means, standard deviations, and numbers of runs with valid results that contributed to the means are provided in Supplemental Table S2 (http://dx.doi. org/10.3168/jds.2015-10163).

\section{EBV Correlations to Other Traits}

Correlations of EBV for survival traits (model B; $\geq 50$ daughters with first calving) to EBV from the routine genetic evaluation (reliability $\geq 0.9$ ) are shown in

Table 4. Phenotypic frequencies, estimates of heritability from model B (3 periods per parity) on the observed scale, and approximated heritabilities on the underlying scale (DL: Dempster and Lerner, 1950) ${ }^{1}$

\begin{tabular}{lcccccc}
\hline & & \multicolumn{2}{c}{$\mathrm{h}^{2}$} & & \multicolumn{2}{c}{$\mathrm{h}^{2}(\mathrm{DL})$} \\
\cline { 3 - 4 } \cline { 5 - 6 } Trait & $\begin{array}{c}\text { Phenotypic } \\
\text { frequency }\end{array}$ & Mean & $\mathrm{SD}$ & & Mean & SD \\
\hline B1.1 & 0.96 & 0.016 & 0.002 & & 0.080 & 0.011 \\
B1.2 & 0.90 & 0.022 & 0.003 & & 0.065 & 0.008 \\
B1.3 & 0.90 & 0.020 & 0.002 & & 0.058 & 0.006 \\
B2.1 & 0.92 & 0.023 & 0.003 & & 0.078 & 0.010 \\
B2.2 & 0.86 & 0.033 & 0.005 & & 0.081 & 0.011 \\
B2.3 & 0.88 & 0.020 & 0.003 & & 0.053 & 0.009 \\
B3.1 & 0.87 & 0.042 & 0.006 & & 0.107 & 0.016 \\
B3.2 & 0.82 & 0.039 & 0.005 & & 0.084 & 0.011 \\
B3.3 & 0.85 & 0.026 & 0.004 & & 0.061 & 0.010 \\
\hline
\end{tabular}

${ }^{1}$ Heritability estimates are shown with means and standard deviations of estimates from the different runs. 


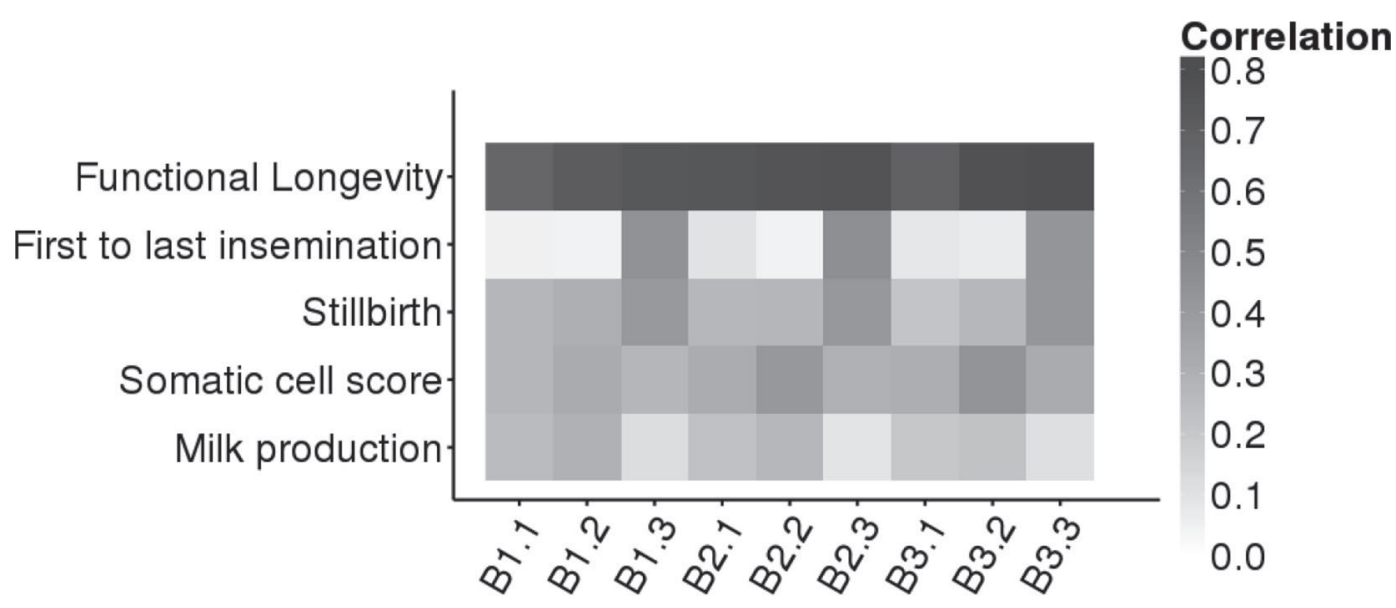

Figure 5. Correlations of estimated breeding values from model B ( 3 periods per parity) to other traits for sires with more than 50 daughters on the data set. Reliabilities of estimated breeding values were required to be $\geq 0.9$. The values, amount of bulls contributing to the different correlation coefficients can be seen in detail in Supplemental Table S3 (http://dx.doi.org/10.3168/jds.2015-10163).

Figure 5. Correlations to EBV for functional longevity $(\mathrm{n}=1,468)$ ranged from 0.67 (B1.1) to 0.79 (B3.3). The EBV correlations to first to last insemination (n $=484)$ were highest to the last periods of all parities (0.43 to 0.46 compared with 0.04 to 0.10 for first and second periods). Correlations to milk production ( $\mathrm{n}=$ $8,743)$ ranged from 0.09 (B2.3) to $0.30(\mathrm{~B} 1.2)$ and were highest to survival traits of the first parity. All values are shown in Supplemental Table S3 (http://dx.doi. org/10.3168/jds.2015-10163).

\section{DISCUSSION}

\section{Data Basis}

With 1,495,441 cows, the data set used for the variance component estimation was larger than in other studies on genetics of survival [Boettcher et al. (1999): 699,722 Canadian Holstein cows; Holtsmark et al. (2009): 800,331 Norwegian Red cows; van Pelt et al. (2015): 112,000 Dutch Holstein cows; Veerkamp et al. (2001): 24,741 UK Holstein cows; Visscher and Goddard (1995): 190,830 Australian Holstein cows]. Although sample size is only one aspect for the quality of genetic parameter estimates, a larger information basis should imply that results are more relevant for practical applications.

Increasing risk of culling over parities was previously reported for US Holstein cows (Hadley et al., 2006; De Vries et al., 2010; Pinedo et al., 2010) and for French dairy cows (Ducrocq, 2005), which is consistent with our results. Furthermore, our results are in line with previously reported peaks of culling risk at the very beginning (Hadley et al., 2006; De Vries et al., 2010) and end (Ducrocq, 2005; Hadley et al., 2006) of a lactation. However, much higher culling rates early in first lactation were reported by Römer (2011) for herds enrolled in a program with increased recording obligations. These data might be more complete compared with data from routine milk recording systems as used in our study. Cows that calved but were disposed before the first test day of the new lactation might, depending on the respective reporting system, not appear in such data. In our study, this effect is particularly expected for the first lactation.

Data for parameter estimation was split into different combination sets of 6 traits per run. For combinations, where the first trait (in this case A1.1 or B1.1) was missing, selection effects on the estimated genetic parameters were expected (Pollak and Quaas, 1981). Although the majority of combinations used in our analysis contained at least 2 traits of the first parity, it was not possible to include the first trait of the first parity in all runs, because the number of necessary combinations would have largely increased. By analyzing the selection effect on genetic parameters that were estimated using multiple different combinations, it was found to be minor on both heritabilities and genetic correlations. For example, the genetic correlation between A3.5 and A3.6 was estimated based on 2 extreme combinations among others: the first included the periods A1.1, A1.2, A2.5, A2.6, A3.5, and A3.6; the other one A3.1, A3.2, A3.3, A3.4, A3.5, and A3.6 (i.e., only third parity traits). Mean estimates for $\mathrm{r}_{\mathrm{g}_{\mathrm{A} 33.5, \mathrm{~A} 3.6}}$ from the different runs were 0.61 and 0.65 , respectively; mean heritability estimates for A3.5 were 0.012 and 0.013 , and for A3.6 0.029 and 0.027 , respectively. 


\section{Distribution of Disposal Reasons}

Pinedo et al. (2010) and Hadley et al. (2006) referred to a slightly different set of disposal reasons in US Holstein cows (reproduction, low production, injury/ other, disease, mastitis, udder problems, feet and legs, died, and reason not reported). Overall frequencies for reproduction and mastitis were similar to disposal reasons infertility and udder diseases, respectively, from our study, but they were lower for feet and legs than for claw and leg disorders in our study. In French Holstein cows, higher overall frequencies were described for reproduction (28.5\%) and low milk yield (16.6\%) as disposal reasons, whereas lameness and foot/leg defects had a much lower frequency $(2.7 \%$; Seegers et al., 1998). Somewhat heterogeneous results of study outcomes may relate to the fact that in many cases a farmer may have more than a single reason to cull a particular cow (Fetrow et al., 2006), but can only report one reason to the breeding organization, which usually will be the main reason from his or her point of view. The relevance of reasons as well as the composition of underlying reasons is likely to change over time and region. Further, the frequency of disposal reasons is influenced by the predefined set of disposal codes. The relatively high amount of "other reasons" in our study indicated room for improvement of documentation around disposals. This could be a more precisely defined code set or an increased motivation for the farmers to accurately report the reasons for disposal, or both. The latter motivation would be difficult to obtain in practice. However, given the stability of the proportion of other reasons over the studied period, this issue did not influence the shape of distributions of other disposal reasons, justifying conclusions based on their patterns. Disposal reasons such as claw and leg disorders, poor milk yield, infertility, udder diseases, and other diseases are obviously linked to heritable traits and can therefore serve as indicators for the contribution of those traits to genetic factors affecting survival at different lactation periods.

\section{Model for Genetic Evaluation}

Proportional hazard models are often considered to suit censored time-to-event data best (e.g., Ducrocq, 1994; Neerhof et al., 2000). However, because computing time was much higher with threshold and survival models (Boettcher et al., 1999), a study of similar extent regarding sample sizes and simultaneous analysis of survival traits would not have been feasible with such models within a reasonable time. Furthermore, using data simulated under a Weibull model, Meuwissen et al. (2002) compared the performance of a proportional hazards model, a threshold model with a logit link function, and a linear model and found very similar correlations between estimated and true breeding values for all methods. Linear multiple trait models for genetic evaluations were previously found to outperform threshold and survival models under practical conditions regarding the ability to predict survival of the first $365 \mathrm{~d}$ in milk for second crop daughters of sires (Holtsmark et al., 2009). The authors of that study assumed that this might be due to the accommodation of multiple genetic effects that could not be applied to the other models in their comparison. As a special case of linear models, random regression models were suggested and successfully used on survival data in the past (Veerkamp et al., 2001; Sasaki et al., 2015; van Pelt et al., 2015). Random regression models have the advantage to keep the number of parameters low and could be an interesting alternative for routine evaluations (Gengler et al., 2005). Sewalem et al. (2005) reported that genetic trends from a Weibull survival model seemed to be overestimated for young sires with a high amount of censored daughter information. The authors explained this overestimation with their model, which kept the parameters of the baseline hazard function constant over time although a systematic trend was present in reality. However, in the German routine genetic evaluation for functional longevity, which allows the parameters of the baseline hazard function to vary over time, lactation, and stage of lactation (VIT, 2015), similar patterns of bias are observed.

\section{Heritability Estimates}

When using linear models on binary response variables, heritability estimates on the observed scale are lower than true heritabilities, with increasing underestimation for more extreme frequencies. Although breeding progress and reliabilities refer to the observed scale, transformation to the underlying scale allows assessing the relative importance of genetic components on different traits with different phenotypic frequencies (Dempster and Lerner, 1950). Heritability estimates on the observed scale for first and last periods of each parity were higher than for other periods due to higher culling frequencies. Sasaki et al. (2015) only found increasing heritabilities toward the end of different lactations, which might be related to the close-to-zero phenotypic variances at the beginning of each lactation in their study. Approximated heritabilities on the underlying scale as proposed by Dempster and Lerner (1950) for model A showed a slightly different pattern (Table 3), with last periods being more similar to survival traits in the middle of the lactation. First periods still tended to show higher heritabilities than the other 
periods. When interpreting these results, it must be taken into account that transformation of heritabilities may have some upward bias for more extreme phenotypic frequencies (Stock et al., 2005).

The relatively high heritability estimates on the observed and approximated underlying scale for the first period of the third parity compared with first and second parities might be explained by an increased incidence of early lactation disorders with higher heritabilities compared with other disorders. This could, for example, be displaced abomasum for which a relatively high heritability has been reported (Zwald et al., 2004). Its incidence is strongly increasing over parities, especially from second to third lactation (K. F. Stock, unpublished data). However, standard deviations of heritability estimates in our study were relatively high compared with the differences between periods, so results should be interpreted with caution.

\section{Genetic Correlation Estimates}

Contrary to heritability estimates of binary response variables from linear models, estimates of genetic correlations are the same on the observed and the underlying scale (Vinson et al., 1976; Gianola, 1982). From model A, 3 genetically homogenous periods per parity could be derived. Genetic background of survival seemed to be similar within each of these periods and distinct from survival of the other periods. Definitions for model B were therefore 0 to 59, 60 to 299, and 300 $\mathrm{d}$ from calving to the subsequent calving.

Although the estimation of genetic correlations between the particular survival traits and other traits was not covered by our study, their direction is indicated by distributions of culling reasons and correlations of EBV for survival traits from model B to EBV of other traits. Both assign survival of different periods to distinct trait complexes: culling for metabolic diseases mostly occurs at the beginning of second and later parities, which might explain why survival of B2.1 and B3.1 (d 0 to 59 from calving in second and third parities) is genetically distinct from survival of other periods and also slightly distinct from survival of B1.1. This hypothesis is also supported by previous studies which found that ketosis and milk fever increase the risk of culling early in lactation whereas the incidence of milk fever is considerably lower in the first parity than in later parities (Beaudeau et al., 1994; Gröhn et al., 1998; Rajala-Schultz and Gröhn, 1999a). Literature further leads to the assumption that survival of the first periods of different parities might be genetically linked to displaced abomasum (Rajala-Schultz and Gröhn, 1999a) and calving traits such as stillbirth (Bicalho et al., 2007).
The mid-lactation period (d 60 to 299 from calving) showed highest EBV correlations to milk production and SCS. Culling within this period is associated with a low milk yield (Rajala-Schultz and Gröhn, 1999c). An association was also found for mastitis (Rajala-Schultz and Gröhn, 1999a; Neerhof et al., 2000), which is genetically correlated with SCS (Rupp and Boichard, 1999; Koeck et al., 2012). Distributions of disposal reasons are consistent with previous studies and support the results of this study: udder diseases showed a peak for the mid-lactation period. From another peak for claw and leg disorders, it might also be assumed that survival of the mid-lactation periods could be genetically related to claw and leg disorders. This assumption is supported by findings from Rajala-Schultz and Gröhn (1999a) and Sogstad et al. (2005) who reported claw disorders to increase the risk of culling and to have highest incidences 3 to 7 mo after calving.

Cows still alive at the end of the last period of each parity (300 d from calving to subsequent calving) must have had a successful reproduction. A delay is probably present between the decision-making for culling and the time point of culling. When the cow did not conceive, she is still milked until her milk yield drops below a threshold of economic profitability. Therefore, infertility was the most frequent reason for disposal in the last period. The EBV correlations of first to last insemination were highest to survival of this period, confirming a genetic association. This was in accordance with results from De Vries et al. (2010), Rajala-Schultz and Gröhn (1999b), and Schneider et al. (2007) who reported increasing risk ratios toward the end of a lactation for culling of open cows compared with pregnant cows. Stillbirth also showed higher EBV correlations with survival of the last parity period compared with other periods. Stillbirth is reported to cause lasting reproductive problems (Bicalho et al., 2007), but also to have an effect on culling early in lactation (Bicalho et al., 2007; Vergara et al., 2014). The latter could not be seen from our results. A possible explanation is that the calving is not always reported for cows that died during or shortly after the calving of a stillborn calf. In this case, culling is erroneously assigned to the last period of the previous parity.

The clearer genetic distinction between periods of the same parity for second and third parity compared with the first parity might be explained by the different distributions of disposal reasons. Although important culling reasons (udder diseases, metabolic diseases, other diseases) show sharp peaks assigned to a single period in later parities, they are more widespread during the first parity. Further, culling reasons mainly belonging to the first parity (poor milk yield, milkability) can 
not only be assigned to the first but also to the midlactation period.

Previous genetic studies using multivariate analysis for survival traits suggested that survival of the first lactation may be genetically distinct from survival of later lactations (Visscher and Goddard, 1995; Boettcher et al., 1999; Veerkamp et al., 2001; Holtsmark et al., 2009). Our study supports this assumption. From the more detailed model A, genetic correlation estimates between periods 1 to 5 of the first parity to the corresponding periods of the second parity were lower $(0.80$ to 0.82 ) than between corresponding periods in second and third parity (0.88 to 0.96 ). The last period was genetically closely correlated across all considered parities indicating that previously found differences in the genetic background of survival between first and later lactations originate from all but the last periods. This pattern was also seen with regard to the frequencies for different disposal reasons. Most differences between first and later parities occurred until $300 \mathrm{~d}$ from calving. Distributions were very similar between second and later parities and toward the end of each parity where infertility consistently became the main reason for disposal in all parities.

The EBV correlations of survival traits from our study to routinely estimated EBV for functional longevity ( 0.67 to 0.79 ) were only moderate, taking into account the similarity of traits. One reason is probably the different trait definition. Functional longevity is defined as longevity corrected for milk yield relative to the herd mean, whereas raw survival was used in the new model. Another explanation might be that survival of each period considered here reflected only parts of the genetic basis of overall longevity.

Correlations of EBV for survival traits to milk production were moderately positive (0.09 to 0.30 ), because survival was not corrected for any measure of voluntary culling. For routinely estimated functional longevity, the genetic correlation to milk production is close to zero (VIT, 2015). The EBV correlations found in our study were similar to genetic correlations estimated by Olori et al. (2002) between milk yield and survival from first to second lactation which was phenotypically corrected for milk yield. Higher genetic correlations were previously estimated between raw survival and milk yield traits (Short and Lawlor, 1992; Visscher and Goddard, 1995; Haile-Mariam et al., 2003). Conversely, Dematawewa and Berger (1998) reported negative genetic correlations of survival to milk yield traits.

In our study, residual covariances were estimated without any pre-assumptions, and resulting residual correlations were close to zero. Visscher et al. (1999) derived that residual covariances for multivariate genetic evaluations for longevity using binary traits and a linear animal model must be zero. Using a sire model for the estimation of variance components, Olori et al. (2002) estimated the residual covariance as 3 times the sire covariance.

\section{Consistency of Results}

For validation of consistency of results over different period definitions and differently split models, parameter estimates were summed up by parity and over all 3 parities using $\mathbf{G}^{*}=\mathbf{W}^{\prime} \mathbf{G} \mathbf{W}$ and $\mathbf{P}^{*}=\mathbf{W}^{\prime} \mathbf{P} \mathbf{W} \cdot \mathbf{G}^{*}$ and $\mathbf{P}^{*}$ are the summarized genetic and phenotypic covariance matrices, $\mathbf{G}$ and $\mathbf{P}$ are the genetic and phenotypic covariance matrices resulting from model $\mathrm{A}$ or $\mathrm{B}$ and $\mathbf{W}$ is an incidence matrix, linking estimates to the desired measurements (i.e., to parities or whole 3 parity survival). For 3 parity survival, $\mathbf{W}^{\prime}$ reduced to $\mathbf{1}^{\prime}$.

The heritability estimates for 3 parity survival were 0.183 and 0.170 for models $\mathrm{A}$ and B, respectively. Further, Table 5 shows estimates for heritabilities and genetic correlations of the complete parities for models $\mathrm{A}$ and B. The results show consistency over different period definitions and differently split models. Patterns for parity-wise genetic parameters were similar to results previously reported (Boettcher et al., 1999), but the estimates for genetic correlations and heritabilities were slightly higher in our study. For survival of the first and third lactation, lower genetic correlations (about 0.65 ) were reported by Veerkamp et al. (2001) and Holtsmark et al. (2009).

\section{CONCLUSIONS}

Our study gives evidence that genetic background of survival varies between different periods of a cow's lifetime. This variation is higher for different periods

Table 5. Genetic correlations (off-diagonal) and heritabilities (diagonal) per parity from model A and B

\begin{tabular}{|c|c|c|c|c|c|c|}
\hline \multirow[b]{2}{*}{ Parity } & \multicolumn{3}{|c|}{ Model A } & \multicolumn{3}{|c|}{ Model B } \\
\hline & 1 & 2 & 3 & 1 & 2 & 3 \\
\hline $\begin{array}{l}1 \\
2 \\
3\end{array}$ & 0.046 & $\begin{array}{l}0.874 \\
0.062\end{array}$ & $\begin{array}{l}0.816 \\
0.967 \\
0.079\end{array}$ & 0.044 & $\begin{array}{l}0.896 \\
0.056\end{array}$ & $\begin{array}{l}0.811 \\
0.981 \\
0.076\end{array}$ \\
\hline
\end{tabular}


of the same parity than for corresponding periods of successive parities. Within each parity, 3 periods with distinct genetic background of survival were derived: 0 to 59,60 to 299 , and $300 \mathrm{~d}$ from calving until the consecutive calving. Most genetic correlations for survival of periods of the first parity to corresponding periods of later parities were lower than respective genetic correlations between second and third parities. The genetic structure corresponded to time-dependent distributions of disposal reasons. Correlation patterns of EBV from the linear multiple trait model to EBV of production and functional traits further confirmed the consistency of estimated genetic parameters. Although many previous studies already touched parts of the research question, our results add new aspects concerning the genetic correlations between different periods of the first 3 parities. They can serve as a basis for developing more accurate models for routine genetic evaluations for longevity, which account for the distinct genetic correlation structure regardless of the actual type of model that will be implemented.

\section{ACKNOWLEDGMENTS}

The German national FBF (Förderverein Bioökonomieforschung e.V.) is thanked for the financial support.

\section{REFERENCES}

Allaire, F. R., and J. P. Gibson. 1992. Genetic value of herd life adjusted for milk production. J. Dairy Sci. 75:1349-1356. http:// dx.doi.org/10.3168/jds.S0022-0302(92)77886-2.

Beaudeau, F., K. Frankena, C. Fourichon, H. Seegers, B. Faye, and J. P. T. M. Noordhuizen. 1994. Associations between health disorders of French dairy cows and early and late culling within the lactation. Prev. Vet. Med. 19:213-231. http://dx.doi.org/10.1016/01675877(94)90090-6.

Bicalho, R. C., K. N. Galvão, S. H. Cheong, R. O. Gilbert, L. D. Warnick, and C. L. Guard. 2007. Effect of stillbirths on dam survival and reproduction performance in Holstein dairy cows. J. Dairy Sci. 90:2797-2803. http://dx.doi.org/10.3168/jds.2006-504

Boettcher, P. J., L. K. Jairath, and J. C. M. Dekkers. 1999. Comparison of methods for genetic evaluation of sires for survival of their daughters in the first three lactations. J. Dairy Sci. 82:1034-1044. http://dx.doi.org/10.3168/jds.S0022-0302(99)75324-5.

Caraviello, D. Z., K. A. Weigel, and D. Gianola. 2004. Comparison between a Weibull proportional hazards model and a linear model for predicting the genetic merit of US Jersey sires for daughter longevity. J. Dairy Sci. 87:1469-1476. http://dx.doi.org/10.3168/ jds.S0022-0302(04)73298-1.

Cleveland, W. S. 1979. Robust locally weighted regression and smoothing scatterplots. J. Am. Stat. Assoc. 74:829-836. http:// dx.doi.org/10.1080/01621459.1979.10481038.

De Vries, A., J. D. Olson, and P. J. Pinedo. 2010. Reproductive risk factors for culling and productive life in large dairy herds in the eastern United States between 2001 and 2006. J. Dairy Sci. 93:613-623. http://dx.doi.org/10.3168/jds.2009-2573.

Dematawewa, C. M. B., and P. J. Berger. 1998. Genetic and phenotypic parameters for 305-day yield, fertility, and survival in Holsteins. J. Dairy Sci. 81:2700-2709. http://dx.doi.org/10.3168/jds. S0022-0302(98)75827-8.
Dempster, E. R., and I. M. Lerner. 1950. Heritability of threshold characters. Genetics 35:212-236.

Ducrocq, V. 1994. Statistical analysis of length of productive life for dairy cows of the Normande breed. J. Dairy Sci. 77:855-866. http://dx.doi.org/10.3168/jds.S0022-0302(94)77020-X.

Ducrocq, V. 1999. Topics that may deserve future attention in survival analysis applied to dairy cattle breeding - Some suggestions. Interbull Bull. 21:181-189.

Ducrocq, V. 2002. A piecewise Weibull mixed model for the analysis of length of productive life of dairy cows. In Proc. 7th World Congress on Genetics Applied to Livestock Production, Montpellier, France.

Ducrocq, V. 2005. An improved model for the French genetic evaluation of dairy bulls on length of productive life of their daughters. Anim. Sci. 80:249-256. http://dx.doi.org/10.1079/ASC41720249.

Fetrow, J., K. V. Nordlund, and H. D. Norman. 2006. Invited Review: Culling: Nomenclature, definitions, and recommendations. J. Dairy Sci. 89:1896-1905. http://dx.doi.org/10.3168/jds.S00220302(06)72257-3.

Gengler, N., S. Vanderick, P. Mayeres, A. Gillon, and C. Croquet. 2005. Genetic evaluation of cow survival using a lactation random regression model. Interbull Bull. 33:176-180.

Gianola, D. 1982. Theory and analysis of threshold characters. J. Anim. Sci. 54:1079-1096. http://dx.doi.org/10.2134/jas1982.5451079x.

González-Recio, O., and R. Alenda. 2007. Genetic relationship of discrete-time survival with fertility and production in dairy cattle using bivariate models. Genet. Sel. Evol. 39:391-404. http://dx.doi. org/10.1051/gse:2007010.

Groeneveld, E. 2006. PEST User's Manual. Institute of Animal Science, Neustadt, Germany.

Groeneveld, E., M. Kovac, and N. Mielenz. 2010. VCE User's Guide and Reference Manual Version 6.0. Institute of Farm Animal Genetics, Friedrich Loeffler Institute, Neustadt, Germany.

Gröhn, Y. T., S. W. Eicker, V. Ducrocq, and J. A. Hertl. 1998. Effect of diseases on the culling of Holstein dairy cows in New York state. J. Dairy Sci. 81:966-978. http://dx.doi.org/10.3168/jds.S00220302(98) 75657-7.

Hadley, G. L., C. A. Wolf, and S. B. Harsh. 2006. Dairy cattle culling patterns, explanations, and implications. J. Dairy Sci. 89:22862296. http://dx.doi.org/10.3168/jds.S0022-0302(06)72300-1.

Haile-Mariam, M., P. J. Bowman, and M. E. Goddard. 2003. Genetic and environmental relationship among calving interval, survival, persistency of milk yield and somatic cell count in dairy cattle. Livest. Prod. Sci. 80:189-200. http://dx.doi.org/10.1016/S03016226(02)00188-4.

Holtsmark, M., B. Heringstad, and J. Ødegård. 2009. Predictive abilities of different statistical models for analysis of survival data in dairy cattle. J. Dairy Sci. 92:5730-5738. http://dx.doi. org/10.3168/jds.2009-2132.

Interbull. 2015. National genetic evaluation forms provided by countries. Accessed Jun. 26, 2015. http://interbull.org/ib/geforms.

Kaplan, E. L., and P. Meier. 1958. Nonparametric estimation from incomplete observations. J. Am. Stat. Assoc. 53:457-481. http:// dx.doi.org/10.1080/01621459.1958.10501452.

Koeck, A., F. Miglior, D. F. Kelton, and F. S. Schenkel. 2012. Alternative somatic cell count traits to improve mastitis resistance in Canadian Holsteins. J. Dairy Sci. 95:432-439. http://dx.doi. org/10.3168/jds.2011-4731.

Meuwissen, T. H. E., R. F. Veerkamp, B. Engel, and S. Brotherstone. 2002. Single and multitrait estimates of breeding values for survival using sire and animal models. Anim. Sci. 75:15-24.

Miglior, F., B. L. Muir, and B. J. Van Doormaal. 2005. Selection indices in Holstein cattle of various countries. J. Dairy Sci. 88:12551263. http://dx.doi.org/10.3168/jds.S0022-0302(05)72792-2.

Neerhof, H. J., P. Madsen, V. P. Ducrocq, A. R. Vollema, J. Jensen, and I. R. Korsgaard. 2000. Relationships between mastitis and functional longevity in Danish Black and White Dairy cattle estimated using survival analysis. J. Dairy Sci. 83:1064-1071. http:// dx.doi.org/10.3168/jds.S0022-0302(00)74970-8.

Olori, V. E., T. H. E. Meuwissen, and R. F. Veerkamp. 2002. Calving Interval and Survival Breeding Values as Measure of Cow Fertil- 
ity in a Pasture-Based Production System with Seasonal Calving. J. Dairy Sci. 85:689-696. http://dx.doi.org/10.3168/jds.S00220302(02)74125-8.

Pinedo, P. J., A. De Vries, and D. W. Webb. 2010. Dynamics of culling risk with disposal codes reported by Dairy Herd Improvement dairy herds. J. Dairy Sci. 93:2250-2261. http://dx.doi. org/10.3168/jds.2009-2572.

Pollak, E. J., and R. L. Quaas. 1981. Monte Carlo study of genetic evaluations using sequentially selected records. J. Anim. Sci. 52:257-264. http://dx.doi.org/10.2134/jas1981.522257x.

Pritchard, T., M. Coffey, R. Mrode, and E. Wall. 2013. Understanding the genetics of survival in dairy cows. J. Dairy Sci. 96:3296-3309. http://dx.doi.org/10.3168/jds.2012-6219.

Rajala-Schultz, P. J., and Y. T. Gröhn. 1999a. Culling of dairy cows. Part I. Effects of diseases on culling in Finnish Ayrshire cows. Prev. Vet. Med. 41:195-208. http://dx.doi.org/10.1016/S01675877(99)00046-X.

Rajala-Schultz, P. J., and Y. T. Gröhn. 1999b. Culling of dairy cows. Part II. Effects of diseases and reproductive performance on culling in Finnish Ayrshire cows. Prev. Vet. Med. 41:279-294. http:// dx.doi.org/10.1016/S0167-5877(99)00045-8.

Rajala-Schultz, P. J., and Y. T. Gröhn. 1999c. Culling of dairy cows, Part III. Effects of diseases, pregnancy status and milk yield on culling in Finnish Ayrshire cows. Prev. Vet. Med. 41:295-309. http://dx.doi.org/10.1016/S0167-5877(99)00047-1.

Römer, A. 2011. Untersuchung zur Nutzungsdauer bei Deutschen Holstein Kühen. Zuchtungskunde 83:8-20.

Roxström, A., and E. Strandberg. 2002. Genetic analysis of functional, fertility-, mastitis-, and production-determined length of productive life in Swedish dairy cattle. Livest. Prod. Sci. 74:125-135. http://dx.doi.org/10.1016/S0301-6226(01)00300-1.

Rupp, R., and D. Boichard. 1999. Genetic parameters for clinical mastitis, somatic cell score, production, udder type traits, and milking ease in first lactation Holsteins. J. Dairy Sci. 82:2198-2204. http://dx.doi.org/10.3168/jds.S0022-0302(99)75465-2.

Sasaki, O., M. Aihara, A. Nishiura, H. Takeda, and M. Satoh. 2015. Genetic analysis of the cumulative pseudo-survival rate during lactation of Holstein cattle in Japan by using random regression models. J. Dairy Sci. 98:5781-5795. http://dx.doi.org/10.3168/ jds.2014-9152.

Schneider, M. del P., E. Strandberg, U. Emanuelson, K. Grandinson, and A. Roth. 2007. The effect of veterinary-treated clinical mastitis and pregnancy status on culling in Swedish dairy cows. Prev. Vet. Med. 80:179-192. http://dx.doi.org/10.1016/j. prevetmed.2007.02.006.

Seegers, H., F. Beaudeau, C. Fourichon, and N. Bareille. 1998. Reasons for culling in French Holstein cows. Prev. Vet. Med. 36:257-271. http://dx.doi.org/10.1016/S0167-5877(98)00093-2.

Sewalem, A., G. J. Kistemaker, V. Ducrocq, and B. J. Van Doormaal. 2005. Genetic analysis of herd life in Canadian dairy cattle on a lactation basis using a Weibull proportional hazards model. J. Dairy Sci. 88:368-375. http://dx.doi.org/10.3168/jds.S00220302(05)72696-5.
Sewalem, A., F. Miglior, G. J. Kistemaker, P. Sullivan, G. Huapaya, and B. J. Van Doormaal. 2007. Short Communication: Modification of genetic evaluation of herd life from a three-trait to a fivetrait model in Canadian dairy cattle. J. Dairy Sci. 90:2025-2028. http://dx.doi.org/10.3168/jds.2006-719.

Short, T. H., and T. J. Lawlor. 1992. Genetic parameters of conformation traits, milk yield, and herd life in Holsteins. J. Dairy Sci. 75:1987-1998. http://dx.doi.org/10.3168/jds.S00220302(92)77958-2.

Sogstad, A., T. Fjeldaas, and O. Østerås. 2005. Lameness and claw lesions of the Norwegian red dairy cattle housed in free stalls in relation to environment, parity and stage of lactation. Acta Vet. Scand. 46:203-217. http://dx.doi.org/10.1186/1751-0147-46-203.

Stock, K. F., H. Hamann, and O. Distl. 2005. Estimation of genetic parameters for the prevalence of osseous fragments in limb joints of Hanoverian Warmblood horses. J. Anim. Breed. Genet. 122:271280. http://dx.doi.org/10.1111/j.1439-0388.2005.00527.x.

Thomsen, P. T., and H. Houe. 2006. Dairy cow mortality. A review. Vet. Q. 28:122-129. http://dx.doi.org/10.1080/01652176.2006.969 5218.

van Pelt, M. L., T. H. E. Meuwissen, G. de Jong, and R. F. Veerkamp. 2015. Genetic analysis of longevity in Dutch dairy cattle using random regression. J. Dairy Sci. 98:4117-4130. http://dx.doi. org/10.3168/jds.2014-9090.

Veerkamp, R. F., S. Brotherstone, B. Engel, and T. H. E. Meuwissen. 2001. Analysis of censored survival data using random regression models. Anim. Sci. 72:1-10.

Vergara, C. F., D. Döpfer, N. B. Cook, K. V. Nordlund, J. A. A. McArt, D. V. Nydam, and G. R. Oetzel. 2014. Risk factors for postpartum problems in dairy cows: Explanatory and predictive modeling. J. Dairy Sci. 97:4127-4140. http://dx.doi.org/10.3168/ jds.2012-6440.

Vinson, W. E., J. M. White, and R. H. Kliewer. 1976. Overall classification as a selection criterion for improving categorically scored components of type in Holsteins. J. Dairy Sci. 59:2104-2114. http://dx.doi.org/10.3168/jds.S0022-0302(76)84494-3.

Visscher, P., R. Thompson, H. Yazdi, G. H. Hill, and S. Brotherstone. 1999. Genetic analysis of longevity data in the UK: Present practice and considerations for the future. Interbull Bull. 21:16-22

Visscher, P. M., and M. E. Goddard. 1995. Genetic parameters for milk yield, survival, workability, and type traits for Australian dairy cattle. J. Dairy Sci. 78:205-220. http://dx.doi.org/10.3168/ jds.S0022-0302(95)76630-9.

VIT. 2015. Estimation of Breeding Values for Milk Production Traits, Somatic Cell Score, Conformation, Productive Life and Reproduction Traits in German Dairy Cattle. Accessed Jun. 26, 2015. http://www.vit.de/fileadmin/user_upload/vit-fuers-rind/ zuchtwertschaetzung/milchrinder-zws-online/Zws_Bes_eng.pdf.

Zwald, N. R., K. A. Weigel, Y. M. Chang, R. D. Welper, and J. S. Clay 2004. Genetic selection for health traits using producer-recorded data. I. Incidence rates, heritability estimates, and sire breeding values. J. Dairy Sci. 87:4287-4294. http://dx.doi.org/10.3168/jds. S0022-0302(04)73573-0. 